\title{
Das Quartär als chronostratigraphische Einheit
}

\author{
ThOMAS LitT $^{*}$
}

Das Quartär als System - traditionell als Eiszeitalter aufgefasst - ist ein Intervall, das durch wechselnde klimatische Extreme (Kalt- und Warmzeiten) gekennzeichnet ist und chronostratigraphisch durch die Serien Pleistozän und Holozän untergliedert wird. Der Begriff wurde formal durch Desnoyers (1829) eingeführt.

Die Grundprinzipien für die Gliederung des Quartärs sind dieselben, die auch für andere chronostratigraphische Einheiten des Phanerozoikum gelten (SALVADOR 1994). Allerdings ist für die Gliederung des Quartärs - im Gegensatz zu anderen Systemen - der Klimawechsel, der in den Sedimentfolgen dokumentiert ist, von entscheidender Bedeutung. Die Klassifikation auf der Grundlage von klimatostratigraphischen Einheiten wie „Glaziale“ und „Interglaziale“ bzw. Warm- und Kaltzeiten besitzt eine lange Tradition und ist in verschiedenen Ländern bzw. Regionen in chronostratigraphischen Standards verankert (GibBARd \& West 2000, GibBARd \& van Kolfschoten 2004, LitT et al. 2005).

Die klimatostratigraphischen Begriffe „Interglazial” und „Interstadial” wurden von JESSEN \& Milthers (1928) aufgrund von paläobotanischen Kriterien definiert, die auch gegenwärtig in Europa allgemein akzeptiert werden. Als Interglazial wird danach ein temperater Abschnitt charakterisiert, dessen klimatisches Optimum mindestens das Klimaniveau des gegenwärtigen Interglazials (Holozän) in derselben Region erreicht hat. Als Interstadial wird ein wärmerer Abschnitt bezeichnet, das entweder zu kurz oder zu kalt war, um das Klimaniveau von einem Interglazial in derselben Region zu erreichen. Von der American Commission on Stratigraphic Nomenclature (1961) wurden für die Klassifikation quartärer Sequenzen folgende Definition eingeführt: "A glaciation is a climatic episode during which extensive glaciers developed, attained a maximum extent, and receded. A stadial is a climatic episode, representing a subdivision of a glaciation, during which a secondary advance of glaciers took place. An interstadial is a climatic episode within a glaciation during which a secondary recession or standstil of glaciers took place. An interglacial is an episode during which the climate was incompatible with the wide extent of glaciers that characterize a glaciation" (zitiert nach GIBBARD \& Kolfschoten 2004). Die Anwendung dieser glazial geprägten Definitionen ist jedoch problematisch, wenn sie auf Gebiete übertragen werden soll, die nicht direkt von Inlandvereisungen betroffen waren. Überdies haben häufig eher kalte als wirklich glaziale Klimabedingungen die Intervalle zwischen voll entwickelten Interglazialen bestimmt. Deshalb ist mittlerweile der Begriff „Kaltzeit“ mehr gebräuchlich als „Glazial“ (GIBBARD \& WeST 2000). Gelegentlich werden auch Begriffe wie Thermomer (relativ warme Perioden mit folgenden Abstufungen: Interglazial, Interstadial, Intervall, Subintervall) und Kryomer (relativ kalte Perioden mit folgenden Abstufungen: Glazial, Stadium, Phase, Staffel) verwendet (LüTTIG 1965a).

Die Grundeinheiten der chronostratigraphischen Gliederung (Stufe/Alter) sind im Quartär bislang nicht international verbindlich festgelegt und benannt worden. Hierin drückt sich offensichtlich die Schwierigkeit aus, bei der starken zeitlichen und räumlichen Variabilität des Klimas im Quartär Kriterien zu finden, die für die Definition der kleinsten chronostratigraphischen Einheiten auf globaler Ebene verwendet werden können. Die Entwicklung regionaler Stratigraphien mit entsprechenden Stratotypen ist deshalb für das Quartär insbesondere im kontinentalen Bereich unabdingbar. Teilweise werden in Nordwesteuropa Kalt- und Warmzeiten als chronostratigraphische Einheiten im Sinne von

\footnotetext{
*Anschrift des Verfassers: Prof. Dr. Thомаs Litт, Institut für Paläontologie, Universität Bonn, Nussallee 8, 53115 Bonn, Email: t.litt@uni-bonn.de
} 
regionalen Stufen gebraucht (z.B. Holsteinian Stage, Eemian Stage, vgl. GiBBARD \& vOn KolfsChOteN 2004). Auch in der Stratigraphischen Tabelle von Deutschland 2002 (STD 2002): Quartär (LiTT et al. 2005) erfolgt die Gliederung in Kaltzeiten und Warmzeiten (Beilage 1). Sie ist also klimatostratigraphisch begründet. Insbesondere bei der Definition und Korrelation von Warmzeiten hat sich die Palynologie durch die Erfassung von Biozonen (Pollen Assemblage Zones, Pollen Abundance Zones) bewährt. Zahlreiche regionalstratigraphische Einheiten und Grenzstratotypen des Quartärs wurden in Deutschland und Europa mittels palyno-stratigraphischer Kriterien definiert.

In den zurückliegenden Jahren wurde die Grenzziehung zwischen Pliozän und Pleistozän kontrovers diskutiert. In Nordwesteuropa (so auch in Nordwestdeutschland) wird bislang der niederländischen Gliederung gefolgt, die Untergrenze des Pleistozäns bzw. des gesamten Quartärs mit der ersten deutlichen Abkühlungsphase zu definieren (Praetiglium), die zu einem markanten Umbau der Flora am Ende des Neogens, nach dem Reuverium, führte (ZAGwiJn 1960, 1963, 1974a). Hierbei kam es zum Aussterben typischer Tertiärgehölze wie Sequoia, Nyssa, Liquidambar, Sciadopitys u.a. Dieser klimatisch bedingte Florenwechsel eignet sich für Korrelationen innerhalb Mitteleuropas und ist überdies durch seine Position knapp oberhalb der paläomagnetisch definierten Gauss-Matuyama-Grenze (2,6 Ma v.h.) gut reproduzierbar. Auf dem 27. Internationalen Geologischen Kongress in Moskau 1984 wurde allerdings das Profil von Vrica (Italien) als GSSP für die Untergrenze des Pleistozäns (Top der Olduvai-Magnetozone, 1,8 Ma v.h.) festgelegt (vgl. Aguirre \& PAsini 1985). Die Zweckmäßigkeit dieser Grenzziehung wurde in den Folgejahren kritisiert, da mit ihr nicht der wirklich erste kalte Klima-Event im späten Känozoikum erfasst wurde (ZAGwiJn 1992, PARTRIDGE 1997, Suc et al. 1997, MAUZ 1998). Die INQUA-Kommission für Quartärstratigraphie, die zum damaligen Zeitpunkt zugleich den Status einer Subkommission innerhalb der Internationalen Kommission für Stratigraphie der IUGS besaß, legte deshalb einen Vorschlag vor, die Untergrenze des Pleistozäns neu zu definieren (Gauss-Matuyama-Grenze, vgl. PARTRIDGE 1997). Den Instruktionen der IUGS folgend, wurde 1998 ein gemeinsames Votum der internationalen Subkommissionen Neogen und Quartär organisiert, wobei allerdings die notwendige 2/3-Mehrheit verfehlt wurde. Somit ist das Profil Vrica als GSSP für die Pleistozän-Basis weiterhin gültig (Beginn des Calabriums). Ein GSSP besitzt nach den internationalen Konventionen für mindestens 10 Jahre Gültigkeit. In der STD 2002: Quartär (Beilage 1) wird deshalb in der Spalte „Globale Gliederung“ diese Grenze berücksichtigt, allerdings setzt in der regionalen Gliederung für das kontinentale Nordwesteuropa (ZAGWIJN 1998) bzw. für Norddeutschland und angrenzende Gebiete (zusammenfassende Übersichten in BENDA 1995) traditionell das Unterpleistozän bereits mit dem Praetiglium ein (vgl. auch Heumann \& LitT 2002).

Auf dem XII. INQUA-Kongress in Ottawa 1987 wurde von der zuständigen stratigraphischen Kommission vorgeschlagen, die paläomagnetisch definierte Brunhes/Matuyama-Grenze (780 ka) auch als Grenze zwischen Unter- und Mittelpleistozän zu nutzen (Richmond 1996). Hierüber besteht international weitgehend Konsens, jedoch steht die Festlegung eines Profils als Grenzstratotyp (GSSP) noch aus. Die Grenze zwischen Mittel- und Oberpleistozän ist bislang ebenfalls nicht formell definiert. Seit den Arbeiten von Woldstedt (1955) und Zeuner (1959) wird zumindest in Europa als Oberpleistozän der Zeitraum des letzten Glazials (Weichsel bzw. Würm) und des letzten Interglazials (Eem) akzeptiert. Den Beginn des letzten Interglazials vor ziemlich genau $126 \mathrm{ka}$ als Mittel-Oberpleistozän-Grenze zu nutzen, bekräftigt neuerdings auch GiBBARD (2003), wobei er als Grenzstratotyp (GSSP) die neu bearbeitete Bohrung vom Amsterdam-Terminal (vAN LEEUwEN et al. 2000) vorschlägt (gleichzeitig auch Parastratotyp für das Eemian). Dieser Vorschlag wird gegenwärtig von einer Arbeitsgruppe der Subcommission on Quaternary Stratigraphy geprüft.

In jüngster Zeit ist der Status des Quartärs als formale stratigraphische Einheit im Sinne einer geologischen Periode angezweifelt worden. Es gibt Vorschläge, den Begriff völlig fallen zu lassen und das Neogen als Periode bis in die Gegenwart zu verlängern (mit Miozän, Pliozän, Pleistozän und Holozän als Epochen, z.B. Steininger 2002, Gradstein et al. 2004). Pillans (2004) schlägt vor, das Quartär als formale chronostratigraphische Einheit zu erhalten, allerdings als Subperiode des Neogens. Die Untergrenze des Quartärs läge dann bei 2,6 Ma v.h., und die Plio-Pleistozän-Grenze bei 1,8 Ma v.h. bliebe davon unberührt. Eine klare Position beziehen dagegen GIBBARD et al. (2005): Das Quartär behält 
den Status einer eigenständigen Periode (mit Pleistozän und Holozän als Epochen). Der Beginn des Quartärs und des Pleistozäns sollte übereinstimmend an der Gauss/Matuyama-Grenze (Untergrenze Gelasium-GSSP bei 2,6 Ma v.h.) festgelegt werden. Das neu zu definierende Pleistozän würde dann das Gelasium mit beinhalten (siehe auch Bowen \& GIBBARD 2006). Das INQUA Executive Committee vertritt mittlerweile ebenfalls diese Auffassung (Open Letter, Quaternary Perspectives 16/1, 2006). Die Subkommission Quartär der Deutschen Stratigraphischen Kommission schließt sich diesem Vorschlag voll und ganz an.

\title{
The Quaternary as a chronostratigraphical unit
}

\author{
Keywords: Quaternary, System, Series, Boundaries
}

The Quaternary as a system - traditionally regarded as an Ice Age - is an interval characterised by alternating climatic extremes (cold and warm stages) and subdivided chronostratigraphically into the Pleistocene and Holocene Series. The term was formally introduced by Desnoyers (1829).

The basic principles underlying the subdivision of the Quaternary are the same as those applying to other chronostratigraphical units of the Phanerozoic (SALVADOR 1994). In contrast to other systems, however, the Quaternary is subdivided mainly on the basis of climate changes, which are recorded in sediment series. The classification based on climatostratigraphical units such as "glacials" and "interglacials" or warm and cold stages has a long tradition and is firmly rooted in chronostratigraphical standards in various countries and regions (Gibbard \& West 2000, GibBard \& van Kolfschoten 2004, LiTT et al. 2005).

The climatostratigraphical terms "interglacial" and "interstadial" were defined by JesSEN \& MiLTHERS (1928) on the basis of palaeobotanical criteria that are still generally accepted in Europe at the present time. An interglacial is understood as a temperate period with a climatic optimum at least as warm as the present-day interglacial (Holocene) climate in the same region. An interstadial is defined as a warmer period that was either too short or too cold to reach the climatic level of an interglacial in the same region. The American Commission on Stratigraphic Nomenclature (1961) introduced the following definition for the classification of Quaternary sequences: "A glaciation is a climatic episode during which extensive glaciers developed, attained a maximum extent, and receded. A stadial is a climatic episode, representing a subdivision of a glaciation, during which a secondary advance of glaciers took place. An interstadial is a climatic episode within a glaciation during which a secondary recession or standstil of glaciers took place. An interglacial is an episode during which the climate was incompatible with the wide extent of glaciers that characterize a glaciation" (quoted after GIBBARD \& KOLFSCHOREN 2004). However, usage of a glacially based nomenclature is problematic if it is applied to non-glaciated regions. In addition, the climatic conditions prevailing in the intervals between fully developed interglacials were frequently cold rather than glacial. This is why the term "cold stage" is now more customary than "glacial" (GiBBARD \& WeSt 2000). Occasionally terms such as thermomer (relatively warm periods subdivided into interglacial, interstadial, interval, subinterval) and cryomer (relatively cold periods subdivided into glacial, stadial, phase, subphase) are used (LüTTIG 1965).

An internationally standard definition of the basic units of Quaternary chronostratigraphy (stage/age) has not yet been agreed. This is evidently due to the difficulty of finding appropriate criteria to define the smallest chronostratigraphical units at the global scale, given the strong variability of Quaternary climate in space and time. Hence, it is essential to develop regional stratigraphies with corresponding stratotypes for the Quaternary, especially in continental regions. Sometimes cold and warm stages are used as chronostratigraphical units in northwestern Europe in the sense of regional stages (e.g. Holsteinian Stage, Eemian Stage, see Gibbard \& van Kolfschoten 2004). The Stratigraphical Table of Germany 2002 (STD 2002): Quaternary (LiTT et al. 2005) also uses the division between cold and warm stages (supplement 1). It is therefore based on climatostratigraphy. Palynology has proved its worth especially 
in the definition and correlation of warm stages by means of biozones (pollen assemblage zones, pollen abundance zones). In Germany and Europe, numerous regional stratigraphical units and boundary stratotypes of the Quaternary were defined with reference to palynostratigraphical criteria.

In the past years the Pliocene/Pleistocene boundary has been a matter of controversy. Hitherto the system used in northwestern Europe (and hence in northwestern Germany) was that of the Netherlands, with the base of the Pleistocene and the entire Quaternary at the first clearly cooler stage (Pretiglian), which led to a distinct floral change at the end of the Neogene, after the Reuverian (ZAGWIJN 1960, 1963, 1974a). At this time some typical Tertiary woody plants became extinct (Sequoia, Nyssa, Liquidambar, Sciadopitys, and others). This climate-induced floral change is appropriate for correlations within central Europe and is well reproducible thanks to its position just above the palaeomagnetically defined Gauss-Matuyama boundary (2.6 Ma BP). At the 27th International Geological Congress in Moscow in 1984, however, the section at Vrica (Italy) was chosen as the GSSP for the base of the Pleistocene (top of the Olduvai magnetozone, 1.8 Ma BP, see AguirRe \& PASINI 1985). In subsequent years this boundary was criticised as inappropriate because it did not include the first really cold climate event in the late Cenozoic (Zagwijn 1992, Partridge 1997, Suc et al. 1997, Mauz 1998). Therefore, the INQUA Commission for Quaternary Stratigraphy, which at that time had the status of a subcommission within the International Commission for Stratigraphy of the IUGS, proposed that the base of the Pleistocene should be re-defined (Gauss-Matuyama boundary, see PARTRIDGE 1997). Following IUGS instructions, a joint vote of the international Neogene and Quaternary subcommissions was organised in 1998, but the proposal did not obtain the necessary two-thirds majority. So the Vrica section is still the valid GSSP for the basal boundary of the Pleistocene (beginning of the Calabrian). According to international conventions a GSSP remains valid for at least 10 years. In STD 2002: Quaternary (supplement 1) the column "Global Division" includes this boundary; however, in the regional division of continental northwestern Europe (ZAGWIJN 1998) and of northern Germany and adjacent regions (summarised in BENDA 1995), the Lower Pleistocene traditionally begins with the Pretiglian (see also Heumann \& LitT 2002).

At the XII INQUA Congress in Ottawa in 1987 the stratigraphical commission suggested that the Brunhes-Matuyama boundary (780 ka) should also serve as the boundary between Lower and Middle Pleistocene (RichmOND 1996). This has met with wide international consensus, yet a boundary stratotype (GSSP) has not yet been established.

Nor has the boundary between Middle and Upper Pleistocene been formally defined. Since WoLDSTEDT (1955) and ZEUNER (1959), the period of the last glacial (Weichselian/ Würmian) and the last interglacial (Eemian) is accepted as the Upper Pleistocene, in Europe at least. GiBBARD (2003) is now also in favour of positioning the boundary between the Middle and Upper Pleistocene at the beginning of the last interglacial, about $126 \mathrm{ka}$ ago. He proposes establishing the re-analysed Amsterdam-Terminal borehole (VAN LEEUWEN et al. 2000) as the boundary stratotype (GSSP) (and also the parastratotype for the Eemian). This suggestion is presently being reviewed by a working group of the Subcommission on Quaternary Stratigraphy.

Recently doubts have been raised about the status of the Quaternary as a formal stratigraphical unit, in the sense of a geological period. It has been proposed that the term should be dropped altogether and the Neogene extended into the present (with the Miocene, Pliocene, Pleistocene and Holocene as epochs, e.g. Steininger 2002, Gradstein et al. 2004). Pillans (2004) suggests retaining the Quaternary as a formal chronostratigraphical unit, but as a subsystem of the Neogene. The lower limit of the Quaternary would then be at 2.6 Ma BP, and the Plio-Pleistocene boundary at 1.8 Ma BP would not be affected. However, GiBBARD et al. (2005) argue that the Quaternary should retain its status as a full period (with Pleistocene and Holocene as its epochs). The beginning of the Quaternary and the Pleistocene should coincide with the Gauss/Matuyama boundary (GSSP of the Gelasian base at 2.6 Ma BP). The Pleistocene would be redefined to include the Gelasian stage (see also Bowen \& GIBBARD 2006). In the meantime the INQUA Executive Committee also shares this opinion (Open Letter, Quaternary Perspectives 16/1, 2006). The Quaternary Subcommission of the German Stratigraphic Commission fully concurs with this proposal. 